\title{
What Are "Human Rights"?
}

\section{Against the "Orthodox" View}

Again, despite its ubiquity in contemporary political-moral discourse, the term "human rights" has no canonical meaning: "The term "human right' is nearly criterionless. There are unusually few criteria for determining when the term is used correctly and when incorrectly - and not just among politicians, but among philosophers, political theorists, and jurisprudents as well." ${ }^{\prime \prime}$ In this book, I am concerned with and focus on international - internationally recognized - human rights. So in this opening chapter I explain (a) what the term "human rights" means in the context of discourse about international human rights and (b) why in the context of that discourse - which is the principal contemporary discourse about human rights - the "orthodox" meaning of the term is mistaken. ${ }^{2}$ I also explain both the sense in which some human rights are legal rights and the sense in which some human rights are moral rights.

\section{1}

What does the term "human rights" mean - what are "human rights" in the context of discourse about international human rights?

When we read the Universal Declaration of Human Rights (UDHR) or any of the several international human rights treaties that now exist, ${ }^{3}$

${ }^{1}$ James Griffin, On Human Rights 14-15 (2008). Cf. Lorrin Thomas, "When We Talk about Human Rights," 6 Humanity 337 (2015). Even the meaning of the term "right" is often unclear. See Lloyd Weinreb, "Natural Law and Rights," in Robert P. George, ed., Natural Law Theory: Contemporary Essays 278, 281 (1992) "[D]espite their ubiquity in our discourse, it is unclear just what a right is."

2 See $\mathrm{n} .11$ and accompanying paragraph.

${ }^{3}$ See, e.g., the International Covenant on Civil and Political Rights and the International Covenant on Economic, Social, and Cultural Rights. The UDHR, the two covenants just cited, and every other human rights document cited in this book are easily accessible on the Internet. 
we see that the document states rules of conduct. More precisely, the document states rules of conduct mainly for government, both rules that direct government not to do something to human beings and rules that direct government to do something for human beings. The principal terminology in which such rules are articulated and discussed, as Jürgen Habermas has emphasized, is the "language" of "human rights":

Notwithstanding their European origins ... [i]n Asia, Africa, and South America, [human rights now] constitute the only language in which the opponents and victim of murderous regimes and civil wars can raise their voices against violence, repression, and persecution, against injuries to their human dignity. ${ }^{4}$

Moreover, the language of human rights entails the language of "duties": To say that $A$ has a right that $B$ not do $X$ to $A$ is to say that $B$ has a duty not to do $\mathrm{X}$ to $\mathrm{A}$; to say that $\mathrm{A}$ has a right that $\mathrm{B}$ do $\mathrm{Y}$ for $\mathrm{A}$ is to say that $\mathrm{B}$ has a duty to do $\mathrm{Y}$ for $\mathrm{A}$.

As the several international human rights treaties illustrate:

- The rights (rules) listed in the treaties directly regulate government actors; in that sense, the duty-bearers are government actors. ${ }^{5}$ However, some rights require government actors to regulate nongovernment actors and thereby indirectly regulate nongovernment actors. ${ }^{6}$ For example, Article 2 of the Convention on the Elimination of All Forms of Discrimination against Women requires state parties "to take all appropriate measures to eliminate discrimination by any person, organization, or enterprise."

${ }^{4}$ Jürgen Habermas, Religion and Rationality: Essays on Reason, God, and Modernity 153-54 (Eduardo Mendieta, ed., 2002).

5 A clarification is in order: I am discussing international human rights treaties. By contrast to such treaties, treaties concerning what is conventionally called "international humanitarian law" directly regulate nongovernment (as well as government) actors. See especially the Rome Statute of the International Criminal Court, http://legal.un.org/icc/statute/ romefra.htm. In the future, there may be one or more international human rights treaties that directly regulate nongovernment actors. Cf. Larry Catá Backer, "Considering a Treaty on Corporations and Human Rights: Mostly Failures but with a Glimmer of Success" (2015), http://ssrn.com/abstract=2652804; Anita Ramasastry and Douglass Cassel, "White Paper: Options for a Treaty on Business and Human Rights," 6 Notre Dame Journal of International and Comparative Law i-x, 1-50 (2015).

6 See Monica Hakimi, "State Bystander Responsibility," 21 European Journal of International Law 314 (2010). 
- Although according to most of the rights listed in the treaties, the rights-holders are all human beings (i.e., all born human beings ${ }^{7}$ ), according to some of the listed rights, the rights-holders are not all human beings but only some.

Article 37 of the Convention on the Rights of the Child (CRC), which is the most widely ratified international human rights treaty, ${ }^{8}$ is an example of an international human right according to which the rights-holders are not all human beings but only some: Article 37 requires government to "ensure that: (a) ... Neither capital punishment nor life imprisonment without possibility of release shall be imposed for offences committed by persons below eighteen years of age." Article 38 of the CRC is another example: Article 38 requires government to "refrain from recruiting any person who has not attained the age of fifteen years into their armed forces."

As Articles 37 and 38 of the CRC reflect, that government may justifiably do something to some human beings does not entail that government may justifiably do the same thing to all human beings; that government may justifiably recruit adults into the military, for example, does not entail that it may justifiably recruit children. Similarly, that government may justifiably decline to do something for some human beings - for example, able-bodied persons - does not entail that that it may justifiably decline to do the same thing for human beings who are disabled. One of the most recent international human rights treaties to enter into force (2008) is the Convention on the Rights of Persons with Disabilities. ${ }^{9}$

In what sense is a right according to which the rights-holders are not all human beings but only some - for example, children - truly a human right? The UDHR states, in Article 1, that "[a]ll human beings ... should act towards one another in a spirit of brotherhood." As the term "human right" is understood both in the UDHR and in all of the several international human rights treaties that have followed in the UDHR's wake, a right is a human right, even if according to the right the rights-holders are

7 The UDHR states, in Article 1, that "[a]ll human beings are born free and equal in dignity and rights ... and should act towards one another in a spirit of brotherhood."

8 As of April 2016, every member of the United Nations except one was a party to the CRC. The one: the United States. See Martha Middleton, "The Last Holdout: The ABA Adds Its Voice to Calls for the United States to Ratify the Convention on the Rights of the Child," ABA Journal, March 2016, at 64.

9 As of April 2016, there were 162 state parties to the Convention on the Rights of Persons with Disabilities. 
not all but only some human beings, if the fundamental rationale for establishing and protecting the right - for example, as a treaty-based right - is that conduct that violates the right violates the imperative to "act towards all human beings in a spirit of brotherhood." That imperative is the normative ground of human rights: Each of the human rights articulated in the UDHR and/or in one or more of the several international human rights treaties - for example, the right, articulated in Article 5 of the UDHR and elsewhere, not to be subjected to "cruel, inhuman or degrading treatment or punishment" 10 - is a specification of what the imperative, in conjunction with all other relevant considerations, is thought to forbid or to require. The fundamental rationale for Articles 37 and 38 of the CRC is that conduct that violates either article fails to act "in a spirit of brotherhood" toward some human beings: children.

John Tasioulas has claimed that the term "human rights" has an "orthodox" meaning, which Tasioulas endorses: "rights possessed by all human beings simply in virtue of their humanity." 11 However, in the context of discourse about international human rights, the orthodox meaning is mistaken. In that context - which is, after all, the principal contemporary discourse about human rights - some human rights, as I have just explained, are rights possessed not by all human beings but only by some - for example, children, or the disabled, or women. For example, Article 12 of the Convention on the Elimination of All Forms of Discrimination against Women, which is one of the most important international human rights treaties, ${ }^{12}$ provides, in relevant part, that "States Parties shall ensure to women appropriate services in connection with pregnancy, confinement and the post-natal period, granting free services where necessary, as well as adequate nutrition during pregnancy and lactation." Again, as the term "human right" is understood both in

${ }^{10}$ Article 5 of the UDHR states: "No one shall be subjected to torture or to cruel, inhuman or degrading treatment or punishment."

11 John Tasioulas, "On the Foundations of Human Rights," in Rowan Cruft, S. Matthew Liao, and Massimo Renzo, eds., Philosophical Foundations of Human Rights 45 (2015) (emphasis added). Tasioulas calls this definition, which he affirms, "the orthodox view." Id.

12 As of April 2016, there were 189 state parties to the Convention on the Elimination of All Forms of Discrimination against Women. The United States, however, was not one of them. See Lisa Baldez, Defying Convention: U.S. Resistance to the U.N. Treaty on Women's Rights (2014). Recall that as of April 2016, every member of the United Nations except the United States was a party to the Convention on the Rights of the Child. See n. 8 . 
the UDHR and in all of the several international human rights treaties that have followed in the UDHR's wake, a right is a human right, even if according to the right the rights-holders are not all but only some human beings, if the fundamental rationale for establishing and protecting the right is that conduct that violates the right violates the imperative to "act towards all human beings in a spirit of brotherhood."

Not all human rights are legal rights in all legal systems. In what sense are some human rights legal rights in some legal systems?

A particular right, including a particular human right, is a legal right in a particular legal system, in a meaningfully practical sense of "legal," if and only if the right is generally enforceable in that legal system. The human right to freedom of religion, for example, is a legal right in, because it is enforceable in, Canada's legal system, but the right is not a legal right, because it is not enforceable (or even recognized), in Saudi Arabia's legal system. (About freedom of religion, see Chapter 4.)

Much more could be said: about different sorts of legal systems - in particular, national, subnational, transnational, and international; about the extent to which a particular right is actually enforced in a particular legal system; and about the efficacy of the penalty or penalties typically imposed, in a particular legal system, for violating a particular right. Suffice it here to say that with respect to a particular human right and a particular legal system, the question may be not - or less - whether the right is a "legal" right in that legal system than to what extent it is.

It bears emphasis that the fact that a right is listed in the UDHR does not mean that the right is a legal right in any legal system, because that a right is listed in the UDHR does not mean that the right is enforceable in any legal system. Indeed, as Eleanor Roosevelt stated, immediately preceding the UN General Assembly's adoption of the UDHR in 1948:

In giving our approval to the [UDHR] today, it is of primary importance that we keep clearly in mind the basic character of the document. It is not a treaty; it is not an international agreement. It is not and does not purport to be a statement of law or of legal obligation. It is a declaration of basic principles of human rights and freedoms, to be stamped with the approval of the General Assembly by a formal vote of its members, and to serve as a common standard of achievement for all nations. ${ }^{13}$

13 Quoted in Marjorie M. Whiteman, 5 Digest of International Law 243 (1965). 
It is noteworthy that, to an extent, Eleanor Roosevelt's hopes have been fulfilled: The UDHR "has served as a model for constitution makers. Countless constitutions written since 1948 contain guarantees that either mirror or draw upon the Declaration."14

Not all human rights are moral rights. In what sense are some human rights moral rights?

Recall that as the term "human right" is understood in the UDHR and in every international human rights treaty, a right is a human right if the fundamental rationale for establishing and protecting the right is that conduct that violates the right violates the "act towards all human beings in a spirit of brotherhood" imperative. Given that understanding of "human right," and assuming that the category "moral rights" includes, whatever else it includes, ${ }^{15}$ rights, the violation of which violates the "act towards all human beings in a spirit of brotherhood" imperative or an equivalent norm, some human rights - the human rights the violation of which truly does violate the "act towards all human beings in a spirit of brotherhood" imperative or an equivalent norm - are moral rights. If we call such human rights "true" human rights, we may say that all true human rights are moral rights.

Some have insisted, however, that "moral" rights are not really rights, that the only genuine rights are legal rights, that so-called "moral" rights are phony (counterfeit, faux, pseudo-) rights. Consider, in that regard, Jeremy Bentham's famous dismissal of the language of "natural" rights:

[1.] Of a natural right who has any idea? I, for my part, have none: a natural right is a round square, - an incorporeal body. What a legal right is I know. I know how it was made. I know what it means when made. To me a right and a legal right are the same thing ... Right and law are correlative terms:

14 A.E. Dick Howard, "A Traveler from an Antique Land: The Modern Renaissance of Comparative Constitutionalism," 50 Virginia Journal of International Law 3, 18 (2009) (citing Hurst Hannum, "The Status of the Universal Declaration of Human Rights in National and International Law," 25 Georgia Journal of International \& Comparative Law 287, 313 (1995-96)).

15 There is no consensus about the meaning of the concept "morality." See, e.g., Jean Porter, "Christian Ethics and the Concept of Morality: An Historical Inquiry," 26 Journal of the Society of Christian Ethics 3 (2006); Paul Bloomfield, ed., Morality and Self-Interest (2008); Joel J. Kupperman, "Why Ethical Philosophy Needs to be Comparative," 85 Philosophy 185 (2010). Cf. Michael Smith, The Moral Problem 3 (1994): "[I]f one thing becomes clear by reading what philosophers in meta-ethics have to say, it is surely that enormous gulfs exist between them, gulfs so wide that we must wonder whether they are talking about a common subject matter." 
as much so as son and father. Right is with me the child of law: from different operations of the law result different sorts of rights. ${ }^{16}$

[2.] Right, the substantive right, is the child of law: from real laws come real rights, but from laws of nature, fancied and invented by poets, rhetoricians, and dealers in moral and intellectual poisons come imaginary rights, a bastard brood of monsters, "gorgons and chimeras dire."17

[3.] Natural rights is simple nonsense: natural and imprescriptible rights, rhetorical nonsense-nonsense upon stilts. ${ }^{18}$

According to Amartya Sen, “[Bentham's] suspicion remains very alive today, and despite the persistent use of the idea of human rights in practical affairs, there are many who see the idea of human rights [understood as moral rights] as no more than 'bawling upon paper,' to use another of Bentham's barbed portrayals of natural rights claims." 19

The fundamental difference between legal rights and moral rights concerns the enforceability of the rights. Legal rights are, as such, enforceable. Social rights, too - rights that, although they do not have the status of law in a particular community, are nonetheless widely regarded by members of the community as authoritative for the community - are, as such, enforceable; members of the community enforce them by shaming those who violate the rights, or by shunning them. In what way, if any, are moral rights - that is, moral rights as such, and not as social or as legal rights - enforceable?

For one who believes that God enforces moral rights by punishing or otherwise holding accountable those who violate the rights, moral rights too are enforceable. But for one who is not a theist - or for a theist who does not believe that God is in the business of holding accountable those who violate moral rights - moral rights are not, as such, enforceable. And for some for whom moral rights are not, as such, enforceable, moral rights are not really "rights" at all. Listen to Raymond Geuss: "[E]ssential to the existence of a set of 'rights' [is] that there be some specifiable and more or less effective mechanism for enforcing them. ${ }^{20}$ Listen, too, to

${ }^{16}$ Jeremy Bentham, "Supply Without Burthen or Escheat Vice Taxation," in Jeremy Waldron, ed., Nonsense Upon Stilts: Bentham, Burke and Marx on the Rights of Man 70, 72-73 (1987).

17 Jeremy Bentham, "Anarchical Fallacies," in id. at 46, 69. ${ }^{18}$ Id. at 53.

19 Amartya Sen, "Elements of a Theory of Human Rights," 32 Philosophy \& Public Affairs 315, 316 (2004).

${ }^{20}$ Raymond Geuss, History and Illusion in Politics 143 (2001). For a critique of Geuss's position, see John Tasioulas, "The Moral Reality of Human Rights," in Thomas Pogge, ed., Freedom from Poverty as a Human Right: Who Owes What to the Very Poor? 75, 79-88 (2007). 
Alasdair MacIntyre: "[W]henever [there is] good reason for describing transactions in [the language of rights], it is always in virtue of the existence ... of some particular set of institutional arrangements requiring description in those terms, and the rights in question therefore will always be institutionally conferred, institutionally recognized and institutionally enforced rights ..."21

Given what Bentham, Geuss, MacIntyre, and others have emphasized, why not just abandon the arguably misleading language of "moral" rights? What is gained, if anything, by using that language?

[T] he ancients and the medievals did not have the notion of a right-was their moral life stunted in some way as a result? Did they lack the tools for dealing with certain aspects of the moral enterprise? Among them moral questions were dealt with in terms of what is [morally] right and wrong, what is in accordance with or required by the natural law, what people ought to do or are obliged to do, but not in terms of what someone has a right to, or has a right to do. ${ }^{22}$

Again, what if anything is gained by using the language of "moral" rights? Here is John Finnis's answer, in his book Natural Law and Natural Rights:

[T] he modern vocabulary and grammar of [moral] rights is [an] instrument for reporting and asserting the requirements or other implications of a relationship of justice from the point of view of the person(s) who benefit(s) from that relationship. It provides a way of talking about "what is just" from a special angle: the viewpoint of the "other(s)" to whom something (including, inter alia, freedom of choice) is owed or due, and who would be wronged if denied that something. ... The modern language of rights provides a supple and potentially precise instrument for sorting out and expressing the demands of justice. ${ }^{23}$

${ }^{21}$ Quoted in Nicholas Wolterstorff, Justice: Rights and Wrongs 32 (2008).

22 Theodore M. Benditt, Rights 3 (1982). John Finnis and James Griffin make much the same point: "[I]t is salutary to bear in mind that the modern emphasis on the power of the right-holder, and the consequent systematic bifurcation between 'right' (including 'liberty') and 'duty', is something that sophisticated lawyers were able to do without for the whole life of classical Roman law." John Finnis, Natural Law and Natural Rights 209-10 (1980). "Ethics ... could do without the discourse of [human] rights and still say all that is necessary to it." Griffin, n. 1, at 94 .

${ }^{23}$ Finnis, n. 22, at 210. Immediately after emphasizing the usefulness of moral-rights talk, John Finnis cautions that such talk "is often, though not inevitably or irremediably, a hindrance to clear thought when the question is: What are the demands of justice?" Id. For a critique of rights talk that hinders "clear thought" about "the demands of justice," see Mary Ann Glendon, Rights Talk: The Impoverishment of Political Discourse (1991). Professor Glendon's critique of some rights talk is not a critique of all rights talk; for 
James Griffin makes a similar but more focused point, in his book On Human Rights; he writes about the usefulness, not of moral-rights talk generally, but of a particular kind of moral-rights talk, namely, humanrights talk:

[T] he discourse [of human rights] has distinct merits. It focuses and gives prominence to obligations that arise, not from social status or special talents and skills, but from the dignity of human status itself. The dignity of human status itself is not the only, or the most, important moral status that human beings have. The case for singling it out is largely practical. Ring-fencing this particular status gives it prominence, ease of transmission, enhanced effectiveness in our social life, and indeed in our moral life, and so on. ${ }^{24}$

For better or worse, the language of rights - especially the language of human rights - is now a common feature of moral discourse throughout the world, and is likely to remain so. Indeed, the language of human rights has become the moral lingua franca. (Look again at the Habermas quote in the third paragraph of this chapter. ${ }^{25}$ ) It is difficult to see that there is anything of consequence to be gained by refusing to make peace with that state of affairs.

I have explained in this chapter what the term "human rights" means in the context of the principal contemporary discourse about human rights: discourse about international human rights. I have also explained both the sense in which some human rights are, in one or more legal systems, legal rights and the sense in which some human rights - "true" human rights - are moral rights.

Now, with those clarifications behind us, let's consider what reason or reasons we have - if indeed we have any reason - to take human rights seriously.

Glendon's embrace of talk about international human rights, see Mary Ann Glendon, A World Made New: Eleanor Roosevelt and the Universal Declaration of Human Rights (2001).

${ }^{24}$ Griffin, n. 1, at 94.

25 And see Nicola Perugini and Neve Gordon, The Human Right to Dominate 22 (2015): "[H]uman rights have become the global lingua franca of global moral speak ... Human Rights, as Costas Douzinas has cogently observed, 'have become the new morality of international relations, a way of conducting politics according to a moral norm and rules ... human rights are now the canonical text for the moral disposition of world affairs."' (Quoting Costas Douzinas, "Humanity, Military Humanism and the New Moral Order," 32 Economy and Society 159 (2003).) 